Долгополов Кирилл Андреевич

кандидат юридических наук, доцент, и. о. заведующего кафедрой уголовного права и процесса

Северо-Кавказского федерального университета

\section{К ВОПРОСУ О СОЦИАЛЬНОЙ ЗНАЧИМОСТИ НАКАЗАНИЯ, НЕ СВЯЗАННОГО С ЛИШЕНИЕМ СВОБОДЫ}

Аннотация:

В статье рассматривается вопрос о социальной важности назначения судами уголовного наказания, не связанного с лишением свободы. Объектом исследования является влияние уголовного наказания на развитие общества, предметом - социальная значимость уголовного наказания, не связанного с лишением свободы. Рассматриваются социальные проблемы, возникающие в результате назначения уголовного наказания, связанного с лишением свободы. Это десоциализация индивида, оказывающегося в данном случае в условиях тюремного сообщества, вытекающая из этого рецидивная преступность, криминализация общества, социальная напряженность. Общество заинтересовано в решении данных проблем, отсюда появляется необходимость создания условий, позволяющих расширить практику назначения наказания, не связанного с лишением свободы, с учетом обстоятельств содеянного. В то же время отмечается, что общество в целом негативно реагирует на смягчение уголовного законодательства. Делается вывод о важности изменения отношения общества к расширению практики назначения наказания, не связанного с лишением свободы, и необходимости формирования механизма, способствующего усвоению обществом способности рассматривать лишение свободы как вынужденную меру, дается ряд рекомендаций в данном направлении.

Ключевые слова:

наказание, не связанное с лишением свободы, социальная значимость, общество.
Dolgopolov Kirill Andreevich

PhD in Law

Associate Professor, Acting Head of Criminal Law and Procedure Department, North Caucasus Federal University

ON THE SOCIAL SIGNIFICANCE OF NON-CUSTODIAL CRIMINAL PENALTIES

Summary:

The study examines the question related to the social importance of non-custodial criminal penalties imposed by the courts. The object of the research is the influence of criminal penalties on the development of society, the subject is the social significance of noncustodial criminal penalties. The social problems arising as a result of the imposition of criminal penalties connected with imprisonment are considered. This is the desocialization of the individual in the conditions of the prison community, the resultant recidivism, the criminalization of society, social tensions. Society is interested in solving these problems, hence the need to create conditions for the expansion of non-custodial penalties practice taking into account the circumstances of the crime. At the same time, it is noted that society as a whole reacts negatively to the mitigation of criminal legislation. The author concludes that it is important to change the attitude of society to the expansion of non-custodial sentencing practice and it is necessary to create a mechanism that helps society learn the ability to consider imprisonment as a forced measure, a number of recommendations are made in this regard.

По данным статистики, в России за последние годы существенно снизилось количество людей, отбывающих наказание в местах лишения свободы [1]. Это произошло по ряду причин: изменение практики назначения наказания лицам, совершившим экономические преступления, декриминализация ряда деяний, увеличение числа случаев назначения наказания, не связанного с лишением свободы и т. д.

Специалисты оценивают данный фракт положительно по нескольким причинам. В частности, указывается, что это позволяет решить проблему переполненности мест лишения свободы, сократить расходы на содержание заключенных, сделать более гуманной систему уголовного наказания [2]. Тем не менее, на наш взгляд, с точки зрения развития социальных процессов наиболее значимым положительным эффектом является то, что благодаря сокращению количества лиц, отбывающих назначенное судом уголовное наказание в местах лишения свободы, увеличивается число тех, кто избежал соприкосновения с системой отношений, сформированной в местах лишения свободы [3, с. 61]. Будучи включенным в эту систему, человек, согласно теории тотальных институтов американского социолога Эрвина Гоффмана, подвергается глубокой десоциализации [4, с. 38]. Таким образом, в данном контексте особое значение для общества приобретают виды наказания, с одной стороны, являющиеся адекватными совершенным деяниям, а с другой - не связанные с лишением свободы. 
Следует сказать, что применение наказаний, не связанных с лишением свободы, находит неоднозначный отклик в обществе. Это объясняется в рамках подхода Эмиля Дюркгейма, который указывал в качестве первичного источника коллективное сознание, не готовое мириться с девиантными поступками. При этом в процессе смены механической солидарности органической солидарностью индивидуализированное общество потеснило доминирование коллективного сознания, тем не менее реакция общества на девиантное поведение осталась достаточно жесткой [5, с. 98].

Данное утверждение характерно для современного российского общества. Значительная часть населения России негативно реагирует на меры государства, направленные на смягчение уголовного законодательства [6]. Опросы, проводимые среди населения, показывают, что 91 \% граждан Российской Федерации считают необходимостью ужесточение мер наказания [7]. Ужесточение наказания по отдельным статьям, в частности за коррупцию, поддерживают $95 \%$ россиян [8]. Идею амнистии ко Дню Победы в Великой Отечественной войне, по данным ВЦИОМ, безусловно поддержали лишь 11 \% опрошенных граждан, при этом более половины данную идею не одобрили [9].

Следователи также не считают залог и домашний арест эффективной мерой, продолжая выходить в суд с ходатайствами об избрании такой меры пресечения, как заключение под стражу [10]. Для судов меры пресечения в виде залога и домашнего ареста тоже не стали реальной альтернативой заключению под стражу [11].

На наш взгляд, такая реакция общества объясняется рядом причин. Значительная часть населения России воспитана в советских традициях, когда социальная значимость смягчения наказания системой не декларировалась. Правоохранительная система также формировалась при СССР и изначально была направлена в первую очередь на наказание, а не исправление индивида [12, с. 74]. В обществе сложился подход, согласно которому система уголовного наказания должна жестко карать с целью заставить человека, подвергшегося суровому наказанию, задуматься о целесообразности повторного совершения преступления, что должно привести к снижению уровня преступности [13].

Тем не менее необходимо учитывать, что назначение наказания, предусматривающего лишение свободы, создает для общества достаточно серьезные проблемы. Одной из важнейших в данном случае является проблема десоциализации индивида, оказавшегося в местах лишения свободы.

Данная проблема рассматривается в рамках научных подходов к социализации, которая, согласно теории Т. Лукмана и П.Л. Бергера, представляется процессом освоения личностью норм и ценностей общества. Они выделяют интернализацию - глубокое усвоение индивидом ценностей и норм конкретного социокультурного контекста [14]. В нашем случае таким контекстом являются места лишения свободы, где, по словам К.В. Королькова, происходит пенитенциарная инклюзия индивида [15, с. 55], заключающаяся в том, что, во-первых, находясь в данных условиях, индивид вынужденно глубоко усваивает ценности и нормы той группы, в которую он попадает - это ценностно-нормативная система сообщества заключенных. Во-вторых, он испытывает давление администрации и работников исправительного учреждения, включающее большой объем запретов и ограничений, а также наказаний за их нарушения. Следует также учитывать сложное психологическое состояние индивида, оказавшегося в заключении на достаточно продолжительный срок. Указанные факторы зачастую приводят его к глубокой десоциализации.

В результате общество получает подвергшегося глубокой десоциализации человека, чья социальная интеграция порою складывается весьма тяжело либо оказывается неудачной, что зачастую вновь способствует попаданию индивида на скамью подсудимых. Об этом свидетельствуют показатели рецидивной преступности: в частности, доля лиц, ранее совершавших преступления, в структуре выявленных лиц, совершивших преступления, увеличилась с 24,4\% в 2003 г. до 47,7 \% в 2013 г., на протяжении пяти лет (2009-2013 гг.) составив в структуре преступности около половины [16]. В 2014 г. повторные преступления в общей структуре составили более половины всех преступлений - 50,7 \%, в 2015 г. - 51,8 \%, в 2016 г. - 54,0 \%, в 2017 г. - 56,0 \% $[17$, с. 3]. В 2018 г. почти каждое второе расследованное преступление $(57,8$ \%) совершено лицами, ранее совершавшими преступления [18]. Также специалисты отмечают высокий уровень латентной преступности, что в свете высокого уровня рецидивной преступности выглядит логичным, поскольку опытного преступника сложнее изобличить [19, с. 4]. Следует отметить, что системного подхода для преодоления проблемы десоциализации лиц, освобождающихся из мест лишения свободы, в Российской Федерации нет [20, с. 118]. Такая работа не ведется и после освобождения человека, т. к. соответствующие организации в России отсутствуют. Государство ограничивается контролем за поведением лиц, освободившихся из мест лишения свободы. Общественные же организации не имеют для этого достаточных полномочий и материальных ресурсов. 
В результате наблюдается рост рецидива, который следует рассматривать как самостоятельную социальную проблему. Увеличение рецидивной преступности серьезно влияет на общую криминализацию общества [21, с. 8], что приводит к росту социальной напряженности. При этом очевидно, что данная проблема, так же как и в случае с десоциализацией, охватывает в основном тех, чье наказание связано с лишением свободы.

В качестве еще одной проблемы следует указать то, что постепенное смягчение уголовного законодательства является одним из показателей развития общества. На протяжении исторического развития происходит постепенное смягчение методов наказания, декриминализация определенных деяний, отказ от применения в качестве наказания смертной казни и т. д.

В решении указанных проблем может помочь расширение практики применения наказаний, не связанных с лишением свободы. Государством в настоящее время предпринимаются меры в данном направлении. Дорожной картой уголовной политики России на 2017-2025 гг. предполагается поэтапное изменение уголовного права Российской Федерации в направлении гуманизации, систематизации и пересмотра наказуемости деяний [22, с. 55]. Принят целый ряд мер, дающих возможность существенно сократить применение мер наказания, связанного с лишением свободы [23].

Тем не менее особую социальную значимость приобретают не только разработка и совершенствование программы разумного смягчения уголовного законодательства, но и изменение отношения общества к такой политике государства. В этой связи очень важным моментом является понимание обществом необходимости гуманизации уголовного законодательства, что, в частности, предполагает расширение практики назначения наказаний, не связанных с лишением свободы [24].

С этой целью, во-первых, необходимо создание механизма, способствующего усвоению обществом способности рассматривать лишение свободы как вынужденную меру, которая может быть применена не к любому человеку, допустившему девиантный поступок, а только к тем, кто совершил тяжкие и особо тяжкие преступления. Такой механизм должен в первую очередь информировать население, относящееся к различным социальным группам и слоям, о важности ограждения представителей общества от пенитенциарной инклюзии, объяснять те преимущества, которые общество может получить в случае расширения практики назначения наказаний, не связанных с лишением свободы. Таким образом, помимо государства в разработке и реализации данного механизма должны участвовать средства массовой информации и общественные организации.

Во-вторых, общественным организациям может быть открыт доступ к контролю за лицами, которым судом назначено наказание, не связанное с лишением свободы. В данном случае важным моментом, способствующим контактности осужденного с контролирующим органом, может стать именно общественный статус организации в отличие от правоохранительных органов.

При этом любая коррекция уголовного законодательства должна производиться исключительно после научно-практических дискуссий с участием экспертов и специалистов и с учетом (в соответствии с мерами по противодействию криминалу) регулярного мониторинга воздействия вносимых изменений на реальное состояние преступности в стране.

\section{Ссылки:}

1. Краткая характеристика уголовно-исполнительной системы [Электронный ресурс] // ФСИH Poccии. URL: http://www.fsin.su/ (дата обращения: 19.06.2020).

2. Дубровина Е.С. Гуманизация уголовного права как тенденция общественного развития // Вестник Московского государственного областного университета. Серия: Юриспруденция. 2018. № 4. С. 161-172. https://doi.org/10.18384/23106794-2018-4-161-172.

3. Корольков К.В. Институциональный механизм защиты подростков от пенитенциарной инклюзии : монографрия. Ставрополь, 2010. $141 \mathrm{c}$.

4. Гофффман Э. Тотальные институты : очерки о социальной ситуации психически больных пациентов и прочих постояльцев закрытых учреждений / пер. с англ. А.С. Салина; под ред. А.М. Корбута. М., 2019. 458 с.

5. Дюркгейм Э. О разделении общественного труда. Метод социологии. М., 1991. 575 с

6. Гуманизация современного уголовного законодательства : монография / В.П. Кашепов, А.А. Гравина, Т.О. Кошаева и др.; под общ. ред. В.П. Кашепова. М., 2015. С. 17-18 ; Петропавловский В.Г. О гуманизации наказания // Буква закона. № 2 (25). 2009. С. 6-9.

7. Россияне требуют ужесточить меры наказания для некоторой категории преступников [Электронный ресурc]. URL: https://news.rambler.ru/crime/42957989-rossiyane-trebuyut-uzhestochit-mery-nakazaniya-dlya-nekotoroy-kategoriiprestupnikov/ (дата обращения: 30.05.2020).

8. Ужесточение наказания по отдельным статьям - в частности, за коррупцию - поддерживает 95 \% россиян [Электронный ресурc]. URL: https://bancrf.ru/oprosy/uzhestochenie-nakazaniya-korruptsionerov-za-rossiyane.php (дата обращения: 30.05.2020).

9. Идею амнистии к 75-летию Победы одобрили менее половины жителей России [Электронный ресурc]. URL: https://armenianreport.com/pubs/247813/ (дата обращения: 03.06.2020). 
10. Фетищева Л.М. Анализ практики применения мер уголовно-процессуального пресечения в отношении лиц, совершивших преступления в сфере предпринимательской деятельности // Вестник Прикамского социального института. 2017. № 3 (78). С. 47-49.

11. Данные судебной статистики [Электронный ресурс] // Официальный сайт Судебного департамента при Верховном суде Российской Федерации. URL: http://www.cdep.ru/index.php?id=79 (дата обращения: 03.06.2020).

12. Корольков К.В. Указ. соч. С. 74

13. Россияне требуют ужесточить меры наказания...

14. Бергер П., Лукман Т. Социальное конструирование реальности. Трактат по социологии знания / пер. Е. Руткевич. М., 1995. 323 с.

15. Корольков К.В. Указ. соч. С. 55.

16. Данные ГИАЦ МВД РФ о состоянии преступности в России за 2003-2013 гг. [Электронный ресурс] // Министерство внутренних дел РФ. URL: http://mvd.ru/presscenter/statistics/reports (дата обращения: 02.06.2020).

17. Комплексный анализ состояния преступности в Российской Федерации и расчетные варианты ее развития : аналитический обзор / Ю.М. Антонян, Д.А. Бражников, М.В. Гончарова и др. М., 2018. 86 с.

18. Краткая характеристика состояния преступности в Российской Федерации за январь-сентябрь 2018 г. [Электронный pecypc]. URL: https://xn-b1aew.xn-p1ai/reports/item/14696015 (дата обращения: 05.06.2020).

19. Комплексный анализ состояния преступности... С. 4.

20. Данные ГИАЦ МВД РФ о состоянии преступности...

21. Комплексный анализ состояния преступности... С. 8.

22. Иванчин А.В. Дорожная карта уголовной политики России на 2017-2025 годы: достоинства и недостатки // Вестник Ярославского государственного университета им. П.Г. Демидова. Серия: Гуманитарные науки. 2017. № 3 (41). С. 54-58.

23. Дубровина Е.С. Указ. соч.

24. Там же.

Редактор, переводчик: Сергейчик Людмила Ивановна 